Психология. Журнал Высшей школы экономики.

2017. T. 14. № 4. C. 766-767. DOI: 10.17323/1813-8918-2017-4-766-767

Факты и размышления

\title{
ПСИХОЛОГИЧЕСКАЯ МИСТЕРИЯ АБСТРАКТНОГО ТЕПЛОВОГО ДВИГАТЕЛЯ
}

\author{
В.А. ЛЕФЕВР
}

Вышло в свет второе издание моей книги «Что такое одушевленность?». Хочу объяснить, чем эта книга отличается от других моих работ.

Рефлексивная теория, которую я развиваю, позволила обьяснить и предсказать многие психологические феномены, но не помогла разрешить ни одной мировой загадки, относящейся к фундаментальной науке. В новом издании я предложил решение одной подобной проблемы. Я вывел из термодинамической модели сознания полный набор гармонических интервалов.

В чем заключается эта проблема? Музыкальным интервалом называется отношение частот двух звуков. Только некоторые интервалы звучат приятно. Их всего, по разным оценкам, 16-18. Например, интервалы октава $(1 / 2)$, квинта $(2 / 3)$ и кварта $(3 / 4)$ звучат хорошо, а интервал $(5 / 7)$ - плохо, в то время как $(4 / 7)-$ хорошо. Отлично звучит интервал
$(15 / 16)$, а интервал $(14 / 15)$ звучит плохо.

Столетия люди пытаются объяснить специфику хорошо звучащих интервалов с помощью идеи резонанса. Однако удовлетворительного объяснения на этом пути так и не было найдено. Это дало возможность знаменитому физику Ричарду Фейнману сказать, что вопрос не сдвинулся с мертвой точки со времен Пифагора.

Термодинамическая модель представляет собой цепочку абстрактных тепловых машин, в которой каждая последующая машина исправляет дефект предшествующей машины, производя работу, равную той, которую предшествуюшая могла дополнительно произвести, но не произвела.

Первая машина интерпретируется как субъект, вторая - как его образ себя, третья - как образ себя, который есть у образа себя, и т.д. Работы, производимые машинами, интерпретируются как эмоции, 
испытываемые субъектом и его последовательными образами себя.

В основе всей этой конструкции лежат два первых закона термодинамики: сохранение энергии и неубывание энтропии, т.е. набор гармонических интервалов связан не с акустикой, а с термодинамикой. Этот факт кардинально меняет наш взгляд на то, как наше сознание связано с мозгом. Тут есть две возможности: первая - сознание порождает- ся термодинамическим процессом, протекающим в мозге; вторая существует некоторый скрытый от нас сегодня фактор, генерирующий этот процесс.

В книге я пытаюсь проанализировать вторую возможность Таким образом, рефлексивная модель серьезно меняет напи представления о связи сознания с мозгом. Тут есть над чем подумать физикам, математикам, психологам, философам, музыковедам. 